\title{
Genetic population of threatened Hopea odorata Roxb. in the protected areas of Vietnam
}

\author{
Đa dạng di truyền quần thể loài Sao Đen đang bị đe dọa ở các khu vục bảo tồn \\ ơ Việt Nam \\ Research article
}

Nguyen, Thi Phuong Trang ${ }^{1}$; Tran, Thu Huong ${ }^{1 *}$; Nguyen, Minh Duc ${ }^{1}$; Sierens, Tim ${ }^{2}$; Triest, Ludwig ${ }^{2}$

${ }^{I}$ Institute of Ecology and Biological Resources, Vietnam Academy of Science and Technology, 18 Hoang Quoc Viet Street, Hanoi, Vietnam; ${ }^{2}$ Plant Biology and Nature Management, Vrije Universiteit Brussel, Pleinlaan 2, 1050 Brussels, Belgium

\begin{abstract}
Hopea odorata Roxb. is widely distributed in lowland forests in Vietnam and native to South-East Asia. Due to over-exploitation and habitat destruction, this species are now threatened and mainly restricted to protected areas for survival. In total, 70 adult individuals of three populations include $\mathrm{BGM}, \mathrm{TP}$ and BE of Hopea odorata were investigated base on nine microsatellite loci. Analysis of molecular variance showed most genetic variation (73\%) was within individuals. The mean values of genetic differentiation among populations was high with $F_{\mathrm{ST}}=0.251$. Allelic richness ranged from $2.444-3.293$, pair wise differentiation was significant. Bayesian cluster analysis and $F_{\mathrm{ST}}$ values suggest three populations of Hopea odorata could be divided into two groups. Individual trees from the BGM and TP populations were more closely related than those of the BE population. Inbreeding within population was not significant, no null allele evidence was found but Evidence for recent bottleneck events were found for the BE population at TPM $=0.01$ suggesting that A reduction in the number of individuals could be the result of overharvesting in the past. This research provides additional useful information for conservation, management, and restoration of populations to the Protection Forestry Department, Vietnam.
\end{abstract}

Sao Đen là loài cây gỗ phân bố rộng rãi trong các khu rùng đất thấp ở Việt Nam và các nuớc Đông Nam Á. Do khai thác quá mức và môi truờng sống bị phá hủy mà loài này đang đứng truớc nguy co bị đe dọa và hiện chỉ còn phân bố giới hạn trong các khu bảo tồn. Chúng tôi đã tiến hành phân tích đa dạng di truyền của ba quần thể loài Sao đen gồm BGM, TP và BE tù 70 mẫu cây truởng thành dựa trên chín locus microsatellite. Kết quả phân tích cho thấy sự đa dạng di truyền xảy ra chủ yếu trong các cá thể (73\%). Giá trị sai khác di truyền giữa các quần thể là khá cao $\left(F_{S T}\right.$ =0.251), hệ số đa dạng alen dao dộng tù 2.444 đến 3.293, sụ sai khác di truyền giữa các quần thể là có ý nghĩa. Kết quả phân tích cấu trúc di truyền và sư sai khác di truyền giữa ba quần thể đều khá cao. Hiện tuợng tư thu phấn xảy ra trong ba quần thể nghiên cứu chura có ý nghĩa, không có các bằng chứng về sư xuất hiện của các alen vô nghĩa (điều mà thường xảy ra khi sủ dụng chung locus microsatellite cho các loài hoặc các chi có mối quan hệ gần gũi). Nguyên lý thắt cổ chai trong di truyền (bottleneck) có khả năng xảy ra ở quần thể BE cho thấy khả năng truớc đây noi đây đã xảy ra sự khai thác quá mức làm số luợng cá thể giảm đột ngột. Nghiên cứu này cung cấp những thông tin về di truyền quan trọng cho cuc Kiểm Lâm trong việc bảo tồn, phục hổi và quản lý bền vững quần thể loài Sao Đen ở Việt Nam.

Keywords: Dipterocarp, Hopea odorata, conservation, population genetics, microsatellite 


\section{Introduction}

Many species of Dipterocarpaceae have predominated in the international tropical timber market, and therefore play an important role in the economy of many Southeast Asian countries (Poore, 1989). The dipterocarps also constitute important timber for domestic needs in the seasonal evergreen forests of Asia. The largest genera in Dipterocarpaceae are Shorea (about 250 species), followed by Hopea (105 species), Dipterocarpus (70 species) and Vatical (65 species). In Vietnam, there are more than 40 known species from six genera (Anisoptera, Hopea, Shorea, Parashorea, Vatica, Dipterocarpus), all native and often endemic. Hopea odorata Roxb. has a scatted distribution in Vietnam, Laos, Cambodia, Thailand, Malaysia, Myanmar and India. In Vietnam, Hopea odorata was found in central highland, Southeast and Thanh Hoa province (Nghia NH, 2005) but like most dipterocarps, a long period of selective logging has reduced the size of stands to small groups of trees or isolated individuals, it is threatened by deforestation, changes in land use systems and exploitation for timber. It has been listed in the critically endangered category (Vulnerable $\mathrm{A} 1 \mathrm{~cd}+2 \mathrm{~cd}$ ) by the International Union for Conservation of Nature (IUCN 2013). The sapwood is pale yellow or greyish yellow turning pale brown on exposure, heartwood yellowish-brown to brownish red sometimes with dark streaks, turning purplish on exposure, with lustrous white resin canals at irregular intervals, becoming dull with age. It is chiefly used for boat-building, dug-out canoes and for construction purposes, where durability and strength are of primary importance. It is also used for carts, presses flooring, roofing, piles, fence-posts, ploughs, furniture, furniture, veneer and a number of other uses. It is a first class sleeper wood.

Best growth of Hopea odorata is obtained in areas with annual rainfall more than $1200 \mathrm{~mm}$ and mean annual temperature of $25^{\circ}-27^{\circ} \mathrm{C}$. It is suitable for rehabilitation of degraded lands and is also widely planted as an ornamental and shade tree. The timber of Hopea odorata is a heavy, strong, light colored hardwood. The bark is rich in tannin suitable for tanning leather; it produces resin, though of inferior quality (rock dammar). Evergreen tree up to $45 \mathrm{~m}$ tall with diameter of $120 \mathrm{~cm}$ and prominent buttress. Leaves are simple and alternate, 10-20 cm long with slightly unequal base. Inflorescence is a branched panicle, terminal or axillary. Flowers are small, unisexual, with 5 pinkish petals with hairs on both sides. As with any other dipterocarp species, mass flowering and fruiting of Hopea odorata is irregular and may occur once in 2 to 3 years. Trees reach reproductive maturity at the age of 8-10 years. The fruits are dispersed

Table 1. Collection locations $\boldsymbol{H}$. odorata populations by wind and seeds germinate readily on falling to the ground. Some Hopea odorata fruits are polyembryonic, one fruit may produce up to seven platets. Apomixis in Hopea odorata has been inferred from embryological studies. Isozyme and DNA profiles of Hopea odorata seedlings revealed genetic variation between multiple seedlings from single seeds indicating sexual and asexual reproduction in this species. Pollen can be dispersed as far as $700 \mathrm{~m}$ by small insects (Mahani, 2002).

Due to the exploitation of these species for their valuable timber and resin by local people and forestry enterprises, their habitats are heavily affected by deforestation, forest fragmentation, and unsustainable management such as selective logging. Logging results in intense fragmented habitats and low density populations. These threaten the long-term survival of the genetic resource of species Hopea odorata.

Conservation and management of a species requires information on the ecological and genetic diversity within and among populations. In order to obtain such information, especially a better understanding of genetic processes, powerful biological techniques are required. Understanding the amount of genetic diversity provides information for the development of conservation strategies and sustainable utilization of a species. Microsatellite markers have been used for dipterocarp studies on gene flow, genetic structure, and mating systems (Ujino et al., 1998; Iwata et al., 2000; Takeuchi et al., 2004; Pandey and Geburek, 2009). Several species showed an overall high level of gene diversity but low overall differentiation such as Dryobalanops aromatica Gaertn. $\left(\mathrm{G}_{\mathrm{ST}}=0.067\right.$, Lim et al., 2001), Shorea leprosula Miq. $\left(\mathrm{G}_{\mathrm{ST}}=0.117\right.$, Lee et al., 2000) and Shorea lumutensis Sym. $\left(\mathrm{G}_{\mathrm{ST}}=0.048\right.$, Lee et al., 2004).

The objective of this study was to investigate the level of genetic variability within and between remnant populations of Hopea odorata in protected areas of Vietnam and to test for potential distance-related effects for local inbreeding using microsatellite markers in adult and aged trees.

\section{Materials and methods}

\subsection{Plant materials}

This research was carried out in three sites in Vietnam including $\mathrm{Bu}$ Gia Map National Park (Binh Phuoc province), Tan Phu Protective forests (Dong Nai province), and Ben En National Park (Thanh Hoa province) (Table 1).

\begin{tabular}{|c|c|c|c|c|c|c|}
\hline Population & $\begin{array}{c}\text { Sample } \\
\text { size }\end{array}$ & Symbols sample & Collection locality & Altitude & Latitude & Longitude \\
\hline $\begin{array}{ll}\text { Bu } & \text { Gia } \\
\text { Map } & \end{array}$ & 23 & $\begin{array}{ll}\text { SDBGM } & 1 \\
\text { SDBGM23 } & \end{array}$ & $->\quad$ Bu Gia Map, Binh Phuoc & $130 \mathrm{~m}$ & $10^{\circ} 56^{\prime} \mathrm{N}$ & $106^{\circ} 59^{\prime} \mathrm{E}$ \\
\hline
\end{tabular}




\begin{tabular}{lllllll} 
Tan Phu & 29 & SDTP1 -> SDTP29 & Tan Phu, Dong Nai & $100 \mathrm{~m}$ & $11^{\circ} 12^{\prime} \mathrm{N}$ & $1^{107^{\circ} 09^{\prime} \mathrm{E}}$ \\
Ben En & 18 & SDBE1 -> SDBE18 & Ben En, Thanh Hoa & $100 \mathrm{~m}$ & $19^{\circ} 35^{\prime} \mathrm{N}$ & $105^{\circ} 30^{\prime} \mathrm{E}$ \\
\hline
\end{tabular}

Parts of the native vegetation at $\mathrm{Bu}$ Gia Map (Binh Phuoc), Ben En (Thanh Hoa), and Tan Phu (Dong Nai) have been destroyed because of agricultural expansion. This has led to an alteration of the spatial distribution and age class structure of trees in these sites. However, vegetation structures were still characterized by three strata.

The inner bark was sampled from 18 to 29 mature trees $(>20 \mathrm{~cm}$ at $\mathrm{dbh})$ that were accessible in each of the three populations, within the natural range of Hopea odorata. The samples were immediately placed into paper envelopes and plastic bags with silica gel, then transferred to Laboratory of Molecular Systematics and Conservation Genetics, Institute of Ecology and Biological Resources, Vietnam Academy of Science and Technology; and stored at $-86^{\circ} \mathrm{C}$ until DNA extraction. The samples were identified on the basis of previous taxonomic treatments of collected specimens from these populations and verified with $r b c \mathrm{~L}$ sequences The GenBank accession number KM 267144 with sequence rbcL Hopea odorata voucher specimens were stored at Botany department, Institute of Ecology and Biological Resources.

\subsection{DNA extraction}

Total DNA was extracted from the samples by using the modified CTAB method proposed by Doyle and Doyle (1987). Liquid nitrogen was added to about $100 \mathrm{mg}$ of each sample, which was then ground by hand. Total DNA yield and purity were assessed by spectrophotometer with OD 260 and OD 280, visualization on $1 \%$ agarose electrophoresis. Stock DNA was diluted to a concentration of $10 \mathrm{ng} / \mu 1$.

\subsection{SSR amplification}

Fifteen SSR primers of the related species Shorea curtisii (Ujino et al. 1998) and Neobalanocarpus (Iwata et al., 2000) were initially tested for cross amplification in five samples. Based on their amplification, nine primers that gave polymorphic PCR products were selected for the examination of the whole sample set (Table 2).

Table 2. Microsatellite sequences of primer pairs for Hopea odorata with SSR loci, primer sequences, repeat motif and number of alleles per locus

\begin{tabular}{|c|c|c|c|c|}
\hline $\begin{array}{l}\text { SSR } \\
\text { locus }\end{array}$ & Repeat motif & Primers sequences & Size (bp) & $\begin{array}{l}\text { Number } \\
\text { of alleles }\end{array}$ \\
\hline \multirow[t]{2}{*}{ Shc9 } & \multirow{2}{*}{$(\mathrm{CT})_{12}$} & F:TTTCTGTATCCGTGTGTTG & \multirow{2}{*}{$235-335$} & \multirow{2}{*}{5} \\
\hline & & R:GCGATTAAGCGGACCTCAG & & \\
\hline \multirow[t]{2}{*}{ Shc2 } & & F: CACGCTTTCCCAATCTG & \multirow{2}{*}{$135-145$} & \multirow{2}{*}{2} \\
\hline & $(\mathrm{CT})_{2} \mathrm{CA}(\mathrm{CT})_{5}$ & R: TCAAGAGCAGAATCCAG & & \\
\hline \multirow[t]{2}{*}{ Shc3 } & \multirow{2}{*}{$(\mathrm{CT})_{8}$} & F:TTGAAGGGAAGGCTATG & \multirow{2}{*}{$115-125$} & \multirow{2}{*}{2} \\
\hline & & R:CTTCTCAACTACCTTACC & & \\
\hline \multirow[t]{2}{*}{ Shc17 } & \multirow{2}{*}{$(\mathrm{CT})_{5} \mathrm{AT}(\mathrm{CT})_{4}$} & F:CTAGAATCCGCCATTTCC & \multirow{2}{*}{$100-111$} & \multirow{2}{*}{1} \\
\hline & & R:CACAAATACGTCTCCATATC & & \\
\hline \multirow[t]{2}{*}{ Shc1 } & \multirow{2}{*}{$\begin{array}{l}(\mathrm{CT})_{8}(\mathrm{CA})_{10} \mathrm{CT} \\
(\mathrm{CA})_{4} \mathrm{CTA}\end{array}$} & F:GCTATTGGCAAGGATGTTCA & \multirow{2}{*}{$130-144$} & \multirow{2}{*}{3} \\
\hline & & R:CTTATGAGATCAATTTGACAG & & \\
\hline \multirow[t]{2}{*}{ Nhe5 } & \multirow{2}{*}{$(\mathrm{CT})_{14}$} & F:GGAGGTGTAAACAAACTCAGTG & \multirow{2}{*}{$113-129$} & \multirow{2}{*}{3} \\
\hline & & R:CTACATAATTGTGCAAACTAGGC & & \\
\hline \multirow[t]{2}{*}{ Nhe19 } & \multirow{2}{*}{$(\mathrm{GA})_{14}$} & F:ATCAGAGTAGCCATGTTGCTTG & \multirow{2}{*}{$198-350$} & \multirow{2}{*}{9} \\
\hline & & R:GGAGAGACTGGGCTTGCTC & & \\
\hline \multirow[t]{2}{*}{ Nhe11 } & \multirow{2}{*}{$(\mathrm{GA})_{19}$} & F:CCATCTGAGGGTGTTGAAAG & \multirow{2}{*}{$144-272$} & \multirow{2}{*}{7} \\
\hline & & R:GAGTAGAAGAAGGCAGGTGATTA & & \\
\hline \multirow[t]{2}{*}{ Nhe4 } & \multirow{2}{*}{$(\mathrm{GA})_{19}$} & F:ACGCAAGCCAACACATCC & \multirow{2}{*}{$214-370$} & \multirow{2}{*}{9} \\
\hline & & R:TTTGCCATTTCACAATCATCAC & & \\
\hline
\end{tabular}

Polymerase Chain Reaction was performed in a $25 \mu 1$ reaction mixture containing $5 \mu$ l of total DNA (equivalent 50ng of DNA), 2,5 $\mu 1$ of 10x PCR buffer, $200 \mathrm{nM}$ of each primer, $1 \mathrm{U}$ of taq DNA polymerase (Omega), 2.5 
$\mathrm{mM} \mathrm{MgCl}_{2}$ and $0,2 \mathrm{mM}$ of each dNTP. PCR reactions were performed in a thermal cycler (Bio-Rad Mycycler) using following conditions: 1 cycle at $95^{\circ} \mathrm{C}$ for 5 mins, followed by 35 cycles at $95^{\circ} \mathrm{C}$ for $1 \mathrm{~min}, 45^{\circ} \mathrm{C}$ for $1 \mathrm{~min}$, $72^{\circ} \mathrm{C}$ for $1 \mathrm{~min}$ and a final extension at $72^{\circ} \mathrm{C}$ for 5 mins. PCR products were separated by capillary electrophoresis on a Qiaxcel system (Qiagen).

\subsection{DNA analysis}

A suite of genetic parameters were calculated using GenAlex (Peakall and Smouse, 2006) and FSTAT (Goudet, 1995), including the number of alleles (A) per locus, allelic richness (Ar) per locus and population, observed (Ho) and expected (He) heterozygosities, the coefficient of excesses of homozygotes or heterozygotes compared with panmictic expectations within populations ( $F_{\text {IS }}, 1000$ permutations), and the genetic differentiation ( $F_{\mathrm{ST}}, 1000$ permutations) between populations. F-statistics were determined after Weir and Cockerham (1984) as used in FSTAT software with Jackknifing procedure applied over loci in deriving significance level. These parameters of population structure are defined as the correlations between pairs of gene within individual (Capf), between individuals in the same population (theta) and within individuals within population (smallf) and are analogous to Wright's $F_{\mathrm{IT}}, F_{\mathrm{ST}}$ and $F_{\mathrm{IS}}$, respectively. Each locus was checked for evidence of null alleles, scoring errors and allele drop out using Micro-checker (Van Oosterhout et al. 2004). We tested for recent bottlenecks in each population under the two-phase model (TPM) with 95\% single-step mutations and 5\% multiple-step mutations (Wilcoxon's test 1-tailed) using BOTTLENECK 1.2.02 (Piry et al., 1999).

Exact tests of deviation from the Hardy-Weinberg equilibrium for all loci and among populations were performed at the significance level $(\mathrm{P}=0.05)$. Significance testing for variance components in the analysis of molecular variance (AMOVA) was implemented on the basis of 1000 permutations. A Neighbor Joining Tree for populations of each species was generated to determine the genetic association among populations by using 1000 permutations in Poptree 2 (Takezaki, 2010). Pairwise $F_{\mathrm{ST}}$-values based on $\theta$ were calculated between all pairs of populations and tested for significant differentiation using 999 permutations. Isolation-by-distance between pairs of populations and their geographical distances was tested with $\theta /(1-\theta)$ considering straight flight distances, log transformed (Rousset, 1997) between populations in a Mantel test using 1000 randomizations (Mantel, 1967). A Bayesian clustering method (Pritchard et al., 2000) was carried out using STRUCTURE version 2.3.4. We tested $\mathrm{K}$ in ten independent runs from 1 to 16 (10,000 burn-in and 50,000 Markov chain Monte Carlo replicates in each run), without using sampling location as a prior to assess convergence of $\ln$ (PD). Runs were carried out assuming admixture and an independent model of allele frequencies. The results were uploaded into Structure Harvester (Earl, 2011), which estimates the most likely K value. The number of clusters was determined from the $\mathrm{K}$ with the highest posterior probability and using the second-order rate of change of the likelihood function $\Delta \mathrm{K}$, as suggested by Evanno et al. (2005).

UPGMA cluster analysis of genetic distances was generated to determine the genetic association among populations by using TFPGA (Miller, 1997).

\section{Results}

\subsection{Genetic variation}

The nine SSR markers produced a total of 41 different alleles ranging in size from $100 \mathrm{bp}$ to $370 \mathrm{bp}$, across all 70 trees of nine populations of Hopea odorata. The proportion of polymorphic loci was high in all populations averaged $76,67 \%$. Allelic richness (Ar) ranged from 2.444 (at $\mathrm{BE}$ ) to 3.293 (BGM), the frequency of observed heterozygotes (Ho) ranged from 0.297 (at TP) to 0.472 (at BE). All three populations showed moderate levels of genetic diversities (Ho and $\mathrm{He}<0.5$ ). The mean of observed heterozygosity (Ho) was 0.366 and higher than the expected $(\mathrm{He}=0.356)$ (Table 3$)$. The $F_{\text {IS }}$ value in $\mathrm{BE}$ populations was -0.198 showed an excess of heterozygotes $\left(F_{\text {IS }}<0\right)$. In contrast, $F_{\text {IS values in TP was }}$ high positive $(0.152)$ indicating a lack of heterozygotes suggesting the presence of null alleles, which are commonly found when microsatellite loci are crossamplified among far-related species or genera. Microchecker results indicated no evidence for scoring error due to stuttering, no evidence for large allele dropout and no null alleles might be present. To determine the population "genetic reduction signatures", characteristic of recent reductions in effective population size, the Wilcoxon's heterozygosity excess test (Piry et al. 1999), standard differential test, sign test and the allel frequancey distribution mode shift analysis (Luikart et al. 1998) were performed using Bottleneck software. According to the data for the heterozygosity excess examined under the two-phase model (TPM), we found evidence of recent population reduction or bottleneck for $\mathrm{BE}$ population of $H$. odorata $(\mathrm{TPM}=0.00976)$.

Table 3. Genetic variation within populations at nine microsatellite loci

\begin{tabular}{llllllll}
\hline Population & $\mathbf{N}$ & $\mathbf{A}$ & $\mathbf{A r}$ & $\mathbf{P}$ & Ho & He & $\boldsymbol{F}_{\text {IS }}$ \\
\hline BGM & 23 & 3.2 & 3.293 & 80 & 0.33 & 0.348 & 0.09 \\
TP & 29 & 2.7 & 2.943 & 70 & 0.297 & 0.338 & 0.152 \\
BE & 18 & 2.2 & 2.444 & 80 & 0.472 & 0.382 & -0.198 \\
Mean & & 2.7 & 2.893 & 76.67 & 0.366 & 0.356 & 0.015 \\
\hline
\end{tabular}


Notes: N, population size; A, mean number of alleles per locus; Ar, mean number of alleles richness; P, the percentage of polymorphic loci; Ho and He, mean observed and expected heterozygosity, respectively; $F_{\text {IS }}$, Wright's inbreeding coefficient with $\mathrm{P}<0.05$.

\subsection{Genetic structure}

Table 4. Analysis of molecular variance of Hopea odorata from nine populations

\begin{tabular}{lllll}
\hline Source of variation & d.f. & Sum of squares & Est.variance component & Total variation (\%) \\
\hline Among populations & 2 & 59.192 & 0.606 & $25 \%$ \\
Among individuals & 67 & 123.530 & 0.040 & $2 \%$ \\
Within individuals & 70 & 123.500 & 1.764 & $73 \%$ \\
Total & $\mathbf{1 3 9}$ & $\mathbf{3 0 6 . 2 2 1}$ & $\mathbf{2 . 4 1 0}$ & $\mathbf{1 0 0 \%}$ \\
\hline
\end{tabular}

Table 5. Amova- $F_{\mathrm{ST}}$ results $\left(F_{\mathrm{IS}}, F_{\mathrm{ST}}\right.$ with $\mathrm{P}$-value after 1000 permutations)

\begin{tabular}{lllll}
\hline & $F_{\mathrm{ST}}$ & $F_{\mathrm{IS}}$ & $F_{\mathrm{IT}}$ & $G_{\mathrm{ST}}$ \\
\hline Hopea odorata & $0.251^{*}$ & $0.022^{\mathrm{NS}}$ & $0.268^{*}$ & 0.193 \\
\hline $\begin{array}{l}\text { Notes: } F_{\text {IS }}, \text { Wright's inbreeding coefficient, with *P }<0.001 \text {; NS: none significant } \\
* * \text { significant at } \mathrm{P}<0.05\end{array}$ & &
\end{tabular}

The AMOVA revealed that most of the variation remains within the individual $(73 \%)$. The proportion among populations and within population was $25 \%$ in Hopea odorata (Table 4$)$. The genetic differentiation $\left(F_{\mathrm{ST}}\right)$ was 0.251 , the total fixation $\left(F_{\mathrm{IT}}\right)$ was 0.268 (Table 5$)$.

\section{Among population variation}

The large differentiation (0.31) was found between populations of Ben En (BE) and Tan Phu (TP) for Hopea odorata, the differentiation between BGM and TP was 0.17 (Table 6).

Table 6. Population pairwise (FST) and significant values.

\begin{tabular}{llll}
\hline & BGM & TP & BE \\
\hline BGM & - & $* *$ & $* *$ \\
TP & 0.17 & - & $* *$ \\
BE & 0.30 & 0.31 & - \\
\hline
\end{tabular}

Bayesian assignment of individuals with structure showed most individuals of Hopea odorata were not mixed (Fig 2). We found two genetic cluster in all populations of Hopea odorata and Hopea hainanensis species.

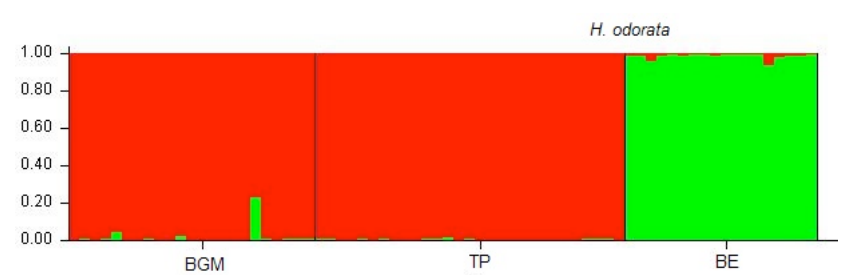

Figure 2. Bayesian assignment

With the $\operatorname{Ln}(\mathrm{PD})$ values were high for $\mathrm{K}=2$. Delta $\mathrm{K}$ values for $H$. odorata were 577.11

A Mantel test within each species gave no significant IBD although a positive trend was obtained for Hopea odorata.

Un-weighted Pair Group Method (UPGMA) analysis based genotype matrix showed the relationship between individuals within species Hopea odorata. All individual studies were separated into two different groups, close relationships between individuals within each group. Group 1 includes individuals of populations Bu Gia Map and Tan Phu, demonstrating a close relationship between the two populations, while the second group consists of individuals of the population Ben En. Methods of distribution are the group into two perfectly matched by coordinates sample collection.

\section{Discussion}

Outcrossing species with a great potential for genetic movement will maintain high levels of genetic diversity within populations and species (Hamrick and Godt, 1989). Information on the high values of genetic diversity from microsatellite loci in dipterocarp species such as Shorea lumutensis $(\mathrm{He}=0.700$, Lee et al., 2004; $\mathrm{He}=$ 0.648, Boshier, 2011), Shorea leprosula ( $\mathrm{He}=0.709$, Rimbawanto and Isoda, 2001; He $=0.686$, Keiya et al., 2001) and at their population levels was reported previously. Our results showed Hopea odorata species had moderate levels of genetic diversity within populations, mean $\mathrm{He}=0.356$. This can be explained from their life strategy because these Hopea odorata species are regionally or narrowly distributed, have a long-life, high fecundity, are predominantly outcrosser, pollinated by insects (Appanah and Chan, 1981) and late successional. Seeds are dispersed over short distances. The TP populations showed lower levels of genetic diversity. This might be due to the smaller available sample size in populations of adults and aged trees, resulting in part from human activities (e.g., logging). Small populations might be subject to within population inbreeding, which can reduce gene diversity. However, 
for three studied populations, the inbreeding levels were none significant. An excess of the heterozygotes appeared in populations of $H$. odorata (Ben En, $F_{\text {IS }}=-0.198$ ) which can be explained from secondary forest and forestry practices.

The differentiation between populations (pairwise $F_{\text {IS }}$ and overall $G_{\mathrm{ST}}$ ) can be explained on basic of geographic distance. Hopea odorata has fairly high $G_{\mathrm{ST}}=0.193$ when compared to other dipterocarp species, such as Dryobalanops aromatica $\left(G_{\mathrm{ST}}=0.067\right.$, Lim et al., 2001), Shorea leprosula $\left(G_{\mathrm{ST}}=0.117\right.$, Lee et al., 2000) and Shorea lumutensis $\left(G_{\mathrm{ST}}=0.048\right.$, Lee et al., 2004). These results for Hopea odorata is in contradiction with the expectation of low variability among populations of longlived and outcrossing species (Hamrick and Godt, 1989). The limited gene flow via either pollen or seed dispersal thus could play an important role in Hopea. Dipterocarp species are insect-pollinated (Appanah and Chan, 1981; Dayanandan et al., 1990) which occurs over only short distances, typically not further than a few kilometers. The high differentiation values at populations have high geographic distance suggest that historical gene exchanges among populations were limited in relation to larger distributional ranges of Hopea odorata even populations from Northern and Southern Vietnam $(\approx 1000$ $\mathrm{km}$ distance). This might indicate genetic depauperation in this species.

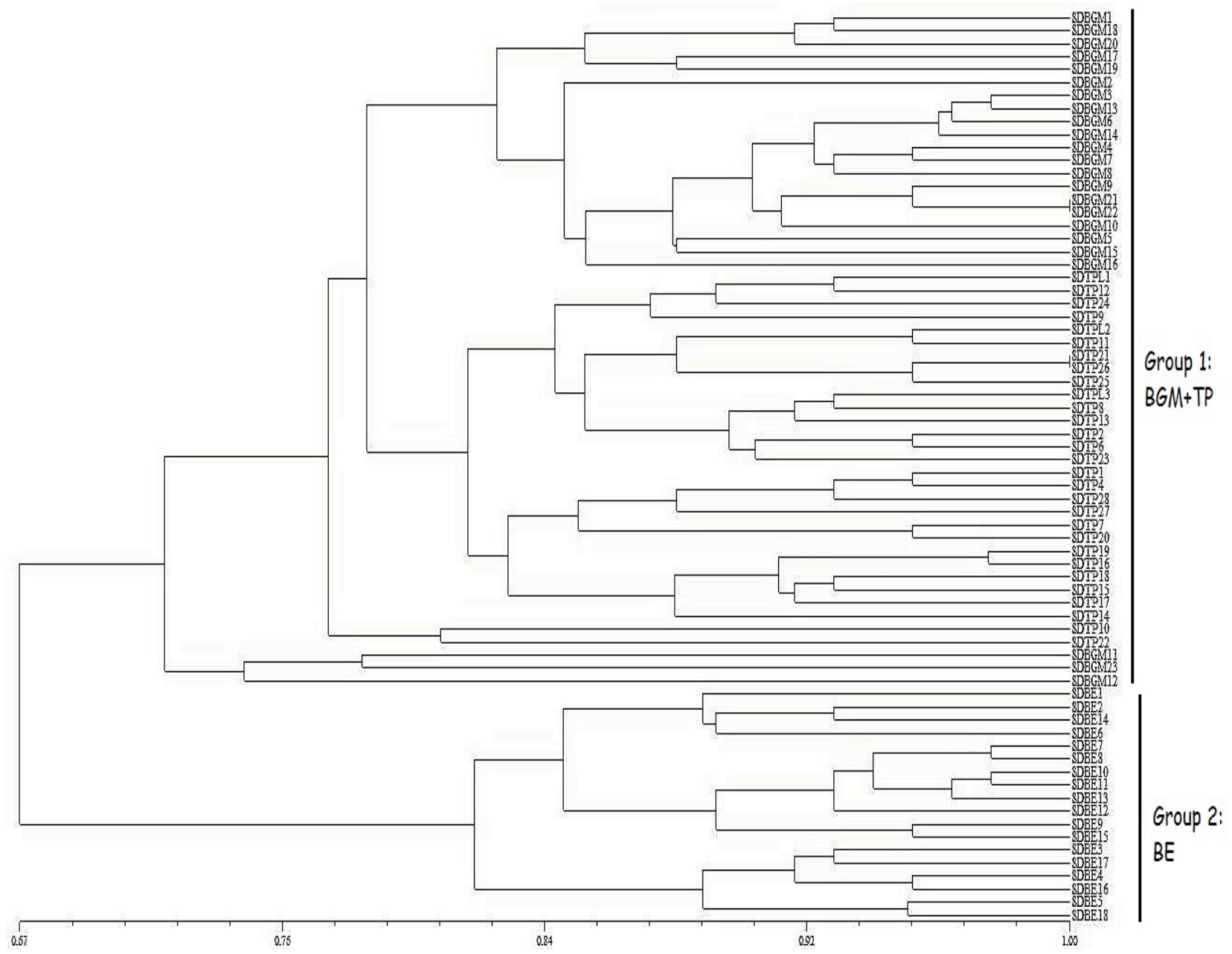

Figure 3. UPGMA analysis based on genetic distance of 70 Hopea odorata individuals

Evidence for bottleneck were found at BE population which mean that in the recent past, the BE population of Hopea odorata was subjected to a reduction in the number of individuals resulting by over harvested in the pass from human activities. Comparing the genetic structure of each species, Bayesian cluster analysis and $F_{\text {ST }}$ values suggested three populations of Hopea odorata could be dived into two groups because of high genetic differentiation. The UPGMA result also confirmed Bayesian analysis when it also divided three populations of Hopea odorata into two clades. The strong genetic differentiation among regions showed that there is a lack of connectivity between populations in each area. But even have strong differentiation, each population of
Hopea odorata still showed high heterozygotes. Our result indicated even these population have small size but they showed high genetic diversity suggesting the forestry protection department should protect and replicate more population of Hopea odorata.

In conclusion, our result give a better understand the genetic implications towards the conservation of threatened Hopea odorata species in Vietnam. There was no evidence for inbreeding and high level of population differentiation. From a conservation point of view, effective management strategies should be worked out for both in situ and ex situ activities. Protection of Hopea odorata species is necessitates survival of populations in 
different protected areas because of the small population sizes of adult trees. This provides additional useful information for conservation, management, and restoration of populations to the Protection Forestry Department, Vietnam.

Our research only used adult individuals because using mature individuals can show the genetic signal of past demographic change. Genetic studies of seedling will provide information about current conditions affecting the genetic variation of the species. Future work can track change in demography and genetic structure with genetic survey performed in next generation.

\section{Acknowledgments}

This research was funded by IEBR.CBT.TS01/14 and BAS42 (Vrije Universiteit Brussel).

\section{References}

[1] Appanah, S. and Chan, H.T. (1981) Thrips: the pollinator of some dipterocarps. Malaysian Forester 44: $234-252$.

[2] Boshier, D. (2011) Shorea lumutensis: genetic variation and conservation. A case study and teacher's notes. In: Boshier D, Bozzano M, Loo J, Rudebjer P (eds.), Forest Genetic Resources Training Guide. Bioversity International, Rome, Italy, p13.

[3] Dayanandan, S., Attygalla, D.N.C., Abeygunasekara AWWL, Gunatilleke IAUN and Gunatilleke CVS (1990) Phenology and floral morphology in relation to pollination of some Sri Lankan dipterocarps. In: Bawa KS and Hadley M (eds.), Reproductive ecology of tropical forest plants, UNESCO, Paris and Parthenon Publishing Group, England: 103-133.

[4] Doyle, J.J and Doyle, J.L. (1987) A rapid DNA isolation procedure for small qualities of fresh leaf material. Phytochemical Bulletin 19: 11-15.

[5] Earl, D.A., Holdt, B.M. (2011) STRUCTURE HARVESTER: a website and program for visualizing STRUCTURE output and implementing the Evanno method. Conservation Genet Res 4: 359-361.

[6] Evanno, G., Regnaut, S., Goudet, J. (2005) Detecting the number of clusters of individuals using the software STRUCTURE: a simulation study. Molecular Ecology 14:2611-2620.

[7] Goudet, J. (1995) FSTat version 1.2: a computer program to calculate F-statistic. J. Hered. 485-486.

[8] Hamrick, J.L. and Godt., M.J.W. (1989) Allozyme diversity in plant species. In: Brown ADH, Cler MT, Kahler AL and Weir BS (eds.) Plant population genetics, Breeding and Genetic Resources. Sinauer, Sunderland, MA: 43-63.

[9] Iwata, H., Konuma, A., Tsumura, Y. (2000) Development of microsatellite markers in the tropical tree Neobalanocarpus heimii (Dipterocarpaceae). Primer notes: 1684-1685.

[10] Keiya, I., Irsyal, Y., Anto, R. and Istiana, P. (2001) Estimation of genetic variation of Drybalanops oblongifolia Dyer. (Dipterocarpaceae) planted in Peninsular Malaysia. In: Thielges BA, Sastrapradja SD and Rimbawanto A (eds.), In-situ and ex-situ conservation of commercial tropical trees, Yogyekarta, Japan: 377- 384.

[11] Lee, S.L., Wickneswari, R., Mahani, M.C. and Zakri, A.H. (2000) Genetic diversity of a tropical species, Shorea leprosula Miq. (Dipterocarpaceae). In Malaysia: implications for conservation of genetic resources and tree improvement. Biotropica 32: 213224.

[12] Lee, S.L., Ng, K.K.S., Lee, C.T., Norwati, M., Saw, L.G. (2004) Shorea lumutensis, an endangered dipterocarp with high levels of genetic diversity but low population differentiation. Conference on Forestry and Forest Products Research: 166-173.

[13] Lim, L.S., Wickneswari, R., Lee, S.L., Latiff, A. (2001) Genetic structure of natural populations of Dryobalanops aromatic Gaertn. F. (Dipterocarpaceae) in Peninsular Malaysia using microsatellite DNA markers. In: Thielges BA, Sastrapradja SD and Rimbawanto A (eds.), In-situ and ex-situ conservation of commercial tropical trees, Yogyekarta, Japan: 309-324.

[14] Luikart, G.L., Allendorf, F.W., Cornuet, J.M., Sherwin, W.B. (1998) Distortion of allele frequency distributions provides a test for recent population bottlenecks, Journal of Heredity 89:238-247.

[15] Mahani, M.C., Jong, K., Ping, Y.C., Fatimah, M., Wickneswari, R. (2002) Triploidy in Hopea odorata. Journal of tropical Forest Science 14(2):264-267.

[16] Mantel, N. (1967) The detection of disease clustering and a generalized regression approach. Cancer Res 27: 209-220.

[17] Miller, M.P. (1997) Tools for population genetic analysis (TFPGA) 1.3: A windows program for the analysis of allozyme and molecular population genetic data.

[18] Nghia, N.H. (2005) Dipterocarps of Vietnam. Agri. pub. hou. 100pp.

[19] Pandey, M. and Geburek, T. (2009) Successful cross-amplification of Shorea microsatellites reveals genetic variation in the tropical tree, Shorea robusta Gaertn. Hereditas 146:29-32.

[20] Peakall, R. and Smouse, P.E. (2006) GENALEX 6: genetic analysis in excel population genetic software for teaching and research. Mol Ecol. Notes 6: 288295.

[21] Piry, S., Luikart, G., Cornuet, J.M. (1999) BOTTLENECK: a computer program for detecting recent reductions in the effective population size using allele frequency data. J Hered 90:502-503. 
[22] Pritchard, J.K., Stephens, M., Donnelly, P. (2000) Inference of population structure using multilocus genotype data. Genetics 155:945 - 959 .

[23] Rimbawanto, A. and Isoda, A.K. (2001) Genetic structure of Shorea leprosula in a single population revealed by microsatellite markers. In: Thielges BA, Sastrapradja SD and Rimbawanto A (eds.), In-situ and ex-situ conservation of commercial tropical trees, Yogyekarta, Japan: 331-338.

[24] Rousset, F. (1997) Genetic differentiation and estimation of gene flow from F-statistics under isolation by distance. Genetics 145: 1219-1228.

[25] Takeuchi, Y., Ichikawa, S., Tomaru, N., Niiyama, K., Lee, S.L., Muhammad, N., Tsumura, Y. (2004) Comparison of the fine-scale genetic structure of three dipterocarp species. Heredity 92: 323-328.
[26] Takezaki, N., Nei, M., Tamura, K. (2010) Software for constructing population trees from allele frequency data and computing other population statistics with Windows interface, Mol Biol Evol, 27 (4): 747-752.

[27] Ujino, T., Kawahara, T., Tsumara, Y., Nagamitsu, T., Yoshimaru, H., Ratnam, W. (1998) Development and polymorphism of simple sequence repeat DNA markers for Shorea curtisii and other Dipterocarpaceae species. Heredity 81: 422-428.

[28] Van, O.C., Hutchinson, W.F., Wills, D.P., Shipley, P. (2004) Micro-checker: software for identifying and correcting genotyping errors in microsatellite data. Mol Ecol Notes 4:535-538.

[29] Weir, B.S. and Cockerham, C.C. (1984) Estimating F-statistics for the analysis of population structure, Evolution (38): 1358-1370. 